\title{
Designing an Assessment to Measure Students' Inferential Reasoning in Statistics: The First Study, Development of a Test Blueprint
}

\author{
PARK, Jiyoon \\ Federation of State Boards, 124 West Street South, Alexandria, VA 22314, USA; \\ Email: parkx666@umn.edu
}

(Received May 21, 2013; Revised December 27, 2013; Accepted December 27, 2013)

\begin{abstract}
Accompanied with ongoing calls for reform in statistics curriculum, mathematics and statistics teachers purposefully have been reconsidering the curriculum and the content taught in statistics classes. Changes made are centered around statistical inference since teachers recognize that students struggle with understanding the ideas and concepts used in statistical reasoning. Despite the efforts to change the curriculum, studies are sparse on the topic of characterizing student learning and understanding of statistical inference. Moreover, there are no tools to evaluate students' statistical reasoning in a coherent way. In response to the need for a research instrument, in a series of research study, the researcher developed a reliable and valid measure to assess students' inferential reasoning in statistics (IRS). This paper describes processes of test blueprint development that has been conducted from review of the literature and expert reviews.
\end{abstract}

Keywords: statistical inference, inferential reasoning in statistics, informal inference, formal inference

MESC Classification: D65

MSC2010 Classification: 97D60

\section{INTRODUCTION}

The ability to draw inferences from data is a part of everyday life as people are confronted with situations where they need to critically review data-based claims (Garfield \& Ben-Zvi, 2008). Understanding of statistical inference is important in scientific research since the concepts and processes in statistical inference are used in all empirical studies (Sotos, Vanhoof, Van den Noortgate \& Onghena, 2007).

Many misunderstandings have been reported that people are confused about the concepts and processes in statistical inference (Falk \& Greenbaum, 1995; Haller \& Kraus, 
2002; Wilkerson \& Olson, 1997; Sotos, Vanhoof, Van den Noortgate, \& Onghena, 2007). For example, Tverky and Kahneman (1971) showed that people believe that any sample must be similar to the population, regardless of its sample size. More recently, there have been studies about people's difficulty understanding hypothesis testing. Specifically, research has revealed that students have difficulty understanding - the definition of the hypotheses (Vallecillos \& Batanero, 1997), the definition of significance level and the $p$ value (Falk, 1986), and the logic of hypothesis testing (Vallecillos, 1999) when they first learn about those concepts.

In the past few years, statistical educators have looked for new ways to help students build an understanding of statistical inference, in light of current research and new developments in the practice of statistics. As a way to support a coherent understanding of the concepts and processes in statistical inference, Wild, Pfannkuch, Regan \& Horton (2011) suggest a learning pathway that introduces some of the "big ideas" behind inference before teaching formal statistical inference. Garfield \& Ben-Zvi (2008) address that ideas of inference should be introduced informally at the beginning of the course, such as having students become familiar with seeing where a sample corresponds to a distribution of sample statistics, based on a theory or hypothesis.

The big ideas of inference that can be taught before formal inference, suggest two content areas in statistical inference-informal statistical inference (ISI) and formal statistical inference (FSI). In this paper, these terms are used to refer to the content areas of statistical inference. The topics of ISI include: the concept of uncertainty; properties of aggregate data; recognizing sampling variability; the concept of unusualness; (informal) generalization from a sample to a population; (informal) comparison between two samples. The concepts involved in formal statistical testing (e.g., p-value, statistical significance, hypothesis tests, confidence intervals) are categorized as FSI. In addition, the topics of foundations of formal statistical inference (e.g., sample representativeness, sample variability, sampling distribution) are also included in this category given that they are foundational to understanding formal statistical inference (e.g., Chance, delMas \& Garfield, 2004).

\section{STUDY PURPOSE AND TARGET POPULATION}

Now that understanding the basic idea of statistical idea is essential in learning statistics (GAISE: American Statistical Association, 2005) and that there have been pervasive misunderstandings about the concepts, it is important to have an assessment tool to better understand how students interpret ideas of statistical inference. Despite increased interest in informal inferential reasoning and efforts to characterize it, there are no assessments of measuring informal reasoning. Studies are sparse on the topic of how informal inferential 
reasoning relates to reasoning about formal statistical inference. There are existing instruments used in statistics education research and evaluation to measure students' reasoning in statistics (e.g., The Statistical Reasoning Assessment (SRA): Garfield, 1998; The Statistics Concepts Inventory (SCI): Reed-Rhoads, Murphy \& Terry, 2006; and the Assessment Resource Tools for Improving Statistical Thinking (ARTIST), Garfield, delMas \& Chance, 2002). Although these instruments assess important outcomes (e.g., assessing students reasoning, thinking, and conceptual understanding), the topics assessed in these instruments do not cover the full domain of reasoning about statistical inference. Moreover, the existing instruments have not been developed or validated using modern measurement models (e.g., item response theory) that provide ample information about properties of test and items (e.g., test validity, item difficulty, item discrimination). Therefore, there is a need for a new instrument that is developed and validated using modern measurement theory so that the results from the assessment provide reliable and valid interpretations. In response to the need for a new research instrument, in a series of study, the researcher describes development processes of an assessment designed to measure students' inferential reasoning in statistics (IRS). As a first step, this paper describes a process of test blueprint development that has been conducted with theoretical and empirical approaches.

Most of the theoretical and empirical data collected in this study is based on education in United States. However, this paper this study can be generalized to a larger population not limited to the students in U.S. given that concepts and content domains in statistical inference are the same across the country. In addition, this assessment is intended to measure reasoning as a latent trait or construct rather than to assess students' current knowledge; the test for the former case is not necessarily related to specific curriculum.

\section{TERMINOLOGIES USED IN THIS STUDY}

Literature about statistical inference uses different terms interchangeably (e.g., statistical inference, inferential reasoning in statistics, and reasoning about statistical inference). Specifically, research literature seems to use the two terms without distinguishing between statistical inference and reasoning about statistical inference. For instance, in Sotos et al. (2007), the researchers use the term statistical inference as a content domain that includes several topics in it. However, in Zieffler, Garfield, delMas \& Reading (2008), statistical inference refers to a reasoning process. To clarify the uses of the terms, this study refers to the term statistical inference as a content domain that involves the concepts and ideas related to inferential statistics. Also, inferential reasoning in statistics (IRS) is used as reasoning that people uses when drawings conclusions from data. 


\section{METHODS}

\subsection{Developing a Test Blueprint from the Literature Review}

In a well-designed test blueprint, it is ensured that there is a sound relationship between the test contents in the blueprint and the construct the proposed test is intended to measure. Then, the test blueprint itself provides evidence based on the test content when it represents the content domain (AERA, APA \& NCME, 1999). In order to make an agreement on the test score interpretation and uses, it is required to decide on the scope of domains that will be covered in the assessment. However, since there is no criterion reference of IRS, the literature of informal and formal statistical inference was reviewed first. After the content domains were chosen, the types of reasoning to be assessed in the domains were specified based on what the previous researchers considered as important to be captured, which resulted in a preliminary test blueprint. Misunderstandings and difficulties in statistical interference found in research literature were also categorized.

\subsection{Expert Review of the Preliminary Test Blueprint}

The preliminary test blueprint was reviewed by content experts, and evaluation reports were gathered to examine the adequacy of the test blueprint as a framework to represent the content domains. According to Testing Standards, qualified experts can judge the representativeness of the chosen test contents, and their judgments of the relationship between parts of the test and the construct also provide evidence based on test content (AERA et al., 1999). The experts who participated in the review process are described below, along with their credentials. The procedures of how they evaluated the preliminary blueprint follow.

\section{Participants}

The preliminary test blueprint developed from the literature was reviewed first by five experts. The two (internal) experts are professionals in the program of statistics education at the University of Minnesota. To recruit external experts in different background (countries, research area focused, etc.), the author contacted eleven potential professionals of statistics educators to ask them to evaluate the test blueprint in early May 2011. These reviewers were selected based on their background and research interests. It was also notable that the pool of reviewers has diversity in terms of their expertise and their level of teaching (Testing Standards 1.7: AERA et al., 1999). The email invitation letter and evaluation form were sent out to each of the potential reviewers, and three of them agreed to participate in the review process for the test blueprint. All three reviewers were statistics educators who were actively engaged researchers in the area of statistics education. The 
first reviewer has published many research studies about students' statistical inference, specifically utilizing technological tools or hands-on activities at the secondary and undergraduate levels in New Zealand.

The second reviewer's expertise is the development of statistics curricula, technological tools, and resources for teaching statistics. He has published in many research journals, specifically about how people elicit and acquire statistical reasoning at work. He is working in the Netherlands.

The third reviewer is an instructor in the Department of Statistics at a college in the Midwest area in the U.S. His expertise is in teaching rather than in research, but he has also been involved in several research projects about the topic of statistical inference. It was expected that his professional experience as a teacher of statistics would provide a valuable perspective in terms of a practical sense of assessing students' inferential reasoning. In addition, he was an introductory statistics textbook author who designed an innovative curriculum focused on developing IRS.

\section{Procedures}

During the entire process of developing a preliminary blueprint, the author had continuous discussions with the internal experts until an agreement was reached for the preliminary blueprint. Thus, only the reviews from the external experts are reported and analyzed in this paper. Feedback on the preliminary test blueprint was collected from the three experts. Each reviewer was provided with a preliminary test blueprint and an evaluation form. The reviewers were asked to provide ratings for their agreement that the test blueprint was adequate as a framework to develop an instrument to assess the IRS in general (See the evaluation form for the questions in Table 1). Specific evaluation questions were also provided, asking the reviewers to rate the degree to which they agreed that the topics and learning goals documented in the blueprint represent the content domain (AERA et al., 1999). The reviewers were also asked to provide suggestions for changes if an item received a rating of less than 2. Items were judged to have a sufficient level of quality if they had a mean rating of 3 (agree) or higher. For items with mean ratings of less than 3, the reviewers' suggestions for the item changes were carefully reviewed and discussed with an internal expert. In addition, the reviewers' comments on the freeresponse evaluation questions (e.g., whether there was anything missing from the content of the blueprint related to the constructs of informal and formal statistical inference) were also considered in revising the blueprint.

The feedback obtained from the reviewers was prioritized, restricting the topics and learning goals that would be included in the test blueprint. However, several times of individual meetings were held with the internal expert to discuss the reviewers' suggestions. To decide whether or not the suggested changes would be made in the blueprint, several 
aspects of the blueprint development were considered such as the scope of the domains (statistical inference, ISI and FSI) delineated from the literature review and topics taught in introductory statistics courses in the U.S. As a result, the final version of the test blueprint was produced.

\section{RESULTS}

\subsection{A Test Blueprint Developed from the Literature Review}

The initial test blueprint was built from the literature about IRS. Representing the content domains of IRS, the literature was centered on two areas: Informal statistical inference (ISI) and Formal statistical inference (FSI). These two content areas were used as structure of a construct IRS providing the scope of the content to be covered in the assessment.

The definitions of the construct IRS, and two content domains ISI and FSI, were revisited. In this study, ISI was defined as a domain of statistical inference that involves informal processes of making arguments to support inferences about unknown populations based on observed samples not necessarily using standard statistical procedures. FSI was defined as a domain of statistical inference that involves making a conclusion about population from samples or to formally test hypotheses, using standard statistical methods. The topic category of sampling distribution was considered to represent foundations of statistical inference. The topic of hypothesis testing was used as the second category representing the concepts and ideas of formal statistical inference. Therefore, two content areas of FSI were considered as the main topics in this domain - sampling distributions and hypothesis testing. As a result, the domains of the blueprint were categorized into three areas: informal inference (Inf), sampling distribution (SD), and hypothesis testing (HT).

For the topic of sampling distributions, five content domains were culled from the literature: the concepts of samples and sampling; the Law of Large Numbers; population distribution and frequency distribution; population distribution and sampling distribution; and the Central Limit Theorem. The literature review resulted in a preliminary test blueprint, which is shown in Appendix A.

\subsection{Expert Review of the Preliminary Test Blueprint}

\section{Results of evaluation ratings}

Three professionals in statistics education provided their feedback and suggestions on the preliminary test blueprint. Table 1 presents the results of the experts' ratings for each 
evaluation question. As shown in the table, the experts generally agreed that the content domains and learning goals listed in the preliminary blueprint represent the target domains of ISI and FSI. It also appeared that the learning goals identified are adequate to assess students' ISI and FSI. However, there are two evaluation questions that one expert assigned to "disagree": question 4 and question 8.

\section{Results of the suggestions and comments}

In addition to the ratings for the questions to evaluate the adequacy of the contents in the test blueprint, the experts were also requested to identify any important content domains in ISI and FSI not listed in the blueprint. There were common suggestions made from two reviewers. First of all, reviewers 1 and 2 suggested including real world applications in the blueprint. Reviewer 1 commented, "There is no attention to the inferences about the real world or contextual knowledge" in the current version. It was also suggested that the current blueprint had too much focus on the "limited population" in the categories of SD (sampling distribution) and HT (hypothesis testing; Reviewers 1 and 3). One of the reviewers noted, "One can conceptualize a process as an infinite, undefined population." Similarly, another reviewer commented that there is no content from an experimental perspective saying, "It only talks about samples from limited populations."

Another common suggestion was provided about the topic of "effect size" (Reviewers 2 and 3). In the category of HT-2, the topic covers definitions of $P$-value and statistical significance. In addition to the $P$-value, a reviewer suggested to include consideration of "how large is the effect," which is related to the concept of the effect size. A similar comment was made by another reviewer with a suggestion of adding the "data quality or soundness of the method" to the current blueprint.

Specific suggestions were also provided regarding additional topics to be included in the test blueprint. The topics are:

- Correlation and regression (Reviewer 1).

- Using models in ISI (Reviewer 1).

- Using meta-cognitive awareness of what inference is as opposed to performing procedures (Reviewer 1).

- Confidence intervals (Reviewer 2).

- In the category of HT-6, add designing a test to compare two groups in an experiment, not just from populations (Reviewer 2).

- Consider including randomization and bootstrapping methods (Reviewer 2).

- In the category SD-2, include "biased sampling" for sampling representativeness (Reviewer 3).

These suggestions were reviewed carefully by the author, and were also reviewed with an internal advisor. Discussion between the author and internal advisor centered around 
whether or not these topics should be included. The definition and the domains that the proposed assessment targets were prioritized for the decision (See Appendix C for the details).

Table 1. Evaluation Questions and Ratings Made by Experts

\begin{tabular}{|c|c|c|c|c|c|}
\hline Item & Evaluation Questions & $\begin{array}{l}\text { Strongly } \\
\text { Agree }\end{array}$ & Agree & $\begin{array}{l}\text { Dis- } \\
\text { agree }\end{array}$ & $\begin{array}{l}\text { Strongly } \\
\text { Disagree }\end{array}$ \\
\hline 1 & $\begin{array}{l}\text { The topics of the blueprint represent the } \\
\text { constructs of informal statistical inference. }\end{array}$ & $X$ & $\mathrm{XX}$ & & \\
\hline 2 & $\begin{array}{l}\text { The topics of the blueprint represent the } \\
\text { constructs of formal statistical inference }\end{array}$ & $\mathrm{X}$ & $\mathrm{XX}$ & & \\
\hline 3 & $\begin{array}{l}\text { The learning goals of the blueprint are ad- } \\
\text { equate for developing items to assess stu- } \\
\text { dents' understanding of informal statistical } \\
\text { inference. }\end{array}$ & $\mathrm{X}$ & $\mathrm{XX}$ & & \\
\hline 4 & $\begin{array}{l}\text { The learning goals of the blueprint are ad- } \\
\text { equate for developing items to assess stu- } \\
\text { dents' understanding of formal statistical } \\
\text { inference. }\end{array}$ & $\mathrm{X}$ & $\mathrm{X}$ & $\mathrm{X}$ & \\
\hline 5 & $\begin{array}{l}\text { The set of learning goals is well supported } \\
\text { by the literature. }\end{array}$ & $\mathrm{X}$ & $\mathrm{XX}$ & & \\
\hline 6 & The learning goals are clearly described. & & $\mathrm{XXX}$ & & \\
\hline 7 & $\begin{array}{l}\text { The categories of the blueprint are well } \\
\text { structured. }\end{array}$ & & XXX & & \\
\hline 8 & $\begin{array}{l}\text { The blueprint provides a framework of } \\
\text { developing a test to assess informal and } \\
\text { formal statistical inference. }\end{array}$ & $\mathrm{X}$ & $\mathrm{X}$ & $\mathrm{X}$ & \\
\hline
\end{tabular}

Table 2 summarizes the changes implemented from the reviewers' comments. The rationale for whether those comments were implemented or not appears in Appendix C. There were topics that the reviewers suggested to include that were not implemented in the blueprint. For example, one reviewer suggested adding content about "correlation and regression." However, these were considered as literacy or part of descriptive statistics rather than a topic of inferential reasoning. Another reviewer commented that ISI might also include "meta-cognitive awareness", but we decided that the topic of meta-cognition does not fit the definition of ISI. In addition, there was no literature found regarding this topic as part of ISI. The changes made from the expert reviews resulted in the final version of the blueprint (See Appendix B). In the last review process of the blueprint, the acronyms representing the topic categories, SD (sampling distribution) and HT (hypothesis tests), were changed to SampD and Stest, respectively, to avoid confusion: in statistics, the acronym of SD is mostly used to represent standard deviation. 
Table 2. Changes to Test Blueprint Implemented from Expert Reviews

\begin{tabular}{|c|c|c|}
\hline $\begin{array}{l}\text { Cate- } \\
\text { gory }\end{array}$ & Changes Suggested & Changes Made in the Blueprint \\
\hline Inf & $\begin{array}{l}\text { Include real world or } \\
\text { contextual knowledge }\end{array}$ & $\begin{array}{l}\text { Added some learning goals to inferential reasoning in a } \\
\text { given context }\end{array}$ \\
\hline Inf & $\begin{array}{l}\text { Include learning goals } \\
\text { about "Using models in } \\
\text { informal inferential rea- } \\
\text { soning" }\end{array}$ & $\begin{array}{l}\text { In two categories, informal inference and formal infer- } \\
\text { ence, the learning goals of setting up the null model in } \\
\text { a given context was added }\end{array}$ \\
\hline Inf & $\begin{array}{l}\text { Include using meta- } \\
\text { cognitive awareness of } \\
\text { what inference is as op- } \\
\text { posed to performing } \\
\text { some techniques }\end{array}$ & Not included in the blueprint \\
\hline $\begin{array}{l}\text { SD } \\
\text { and } \\
\text { HT }\end{array}$ & $\begin{array}{l}\text { Too focused on the lim- } \\
\text { ited population: Add a } \\
\text { process as an infinite } \\
\text { (undefined) population; } \\
\text { Add statistical testing in } \\
\text { experiments }\end{array}$ & $\begin{array}{l}\text { Added the topic categories, DE (designs of study) and } \\
\text { EV (evaluation of study) to capture students' under- } \\
\text { standing of the characteristics of different types of } \\
\text { studies }\end{array}$ \\
\hline HT & $\begin{array}{l}\text { Include the learning } \\
\text { goals about an under- } \\
\text { standing of effect size }\end{array}$ & $\begin{array}{l}\text { In a new category of } \mathrm{EV} \text {, added the learning goal, "Be- } \\
\text { ing able to evaluate the results of hypothesis testing } \\
\text { considering - sample size, practical significance, ef- } \\
\text { fect size, data quality, soundness of the method, etc." }\end{array}$ \\
\hline HT & $\begin{array}{l}\text { Include data quality, } \\
\text { soundness of the method } \\
\text { etc. }\end{array}$ & $\begin{array}{l}\text { The topic category, "Evaluation of HT (EV)," was sep- } \\
\text { arated out from the Hypothesis Testing categories since } \\
\text { this topic is more about assessing how to interpret and } \\
\text { evaluate the results from statistical testing by integrat- } \\
\text { ing different kinds of information in a given study } \\
\text { (e.g., random assignment, sample size, data quality). } \\
\text { The learning goal about, "Being able to evaluate the } \\
\text { results of hypothesis testing (considering sample size, } \\
\text { practical significance, effect size, data quality, sound- } \\
\text { ness of the method, etc.)," was included in this EV cat- } \\
\text { egory. }\end{array}$ \\
\hline $\begin{array}{l}\text { SD } \\
\text { or } \\
\text { HT }\end{array}$ & $\begin{array}{l}\text { Include a topic category } \\
\text { on Confidence Intervals }\end{array}$ & $\begin{array}{l}\text { The topic category, "Inference about Confidence Inter- } \\
\text { val, CI" was added. }\end{array}$ \\
\hline SD-2 & $\begin{array}{l}\text { Add a topic of recogniz- } \\
\text { ing "biased sampling" } \\
\text { for sampling representa- } \\
\text { tiveness }\end{array}$ & $\begin{array}{l}\text { The topic of the "Law of Large Numbers" was changed } \\
\text { to "sample representativeness" to assess whether stu- } \\
\text { dents realize the importance of unbiased sampling } \\
\text { (quality of samples), in addition to a large sample } \\
\text { (sample size) }\end{array}$ \\
\hline HT-6 & $\begin{array}{l}\text { Add designing a test to } \\
\text { compare two groups in } \\
\text { an experiment }\end{array}$ & $\begin{array}{l}\text { In ST-3 (changed from a category of HT), the learning } \\
\text { goal, "designing a statistical test to compare two } \\
\text { groups in an experiment," was added. }\end{array}$ \\
\hline
\end{tabular}




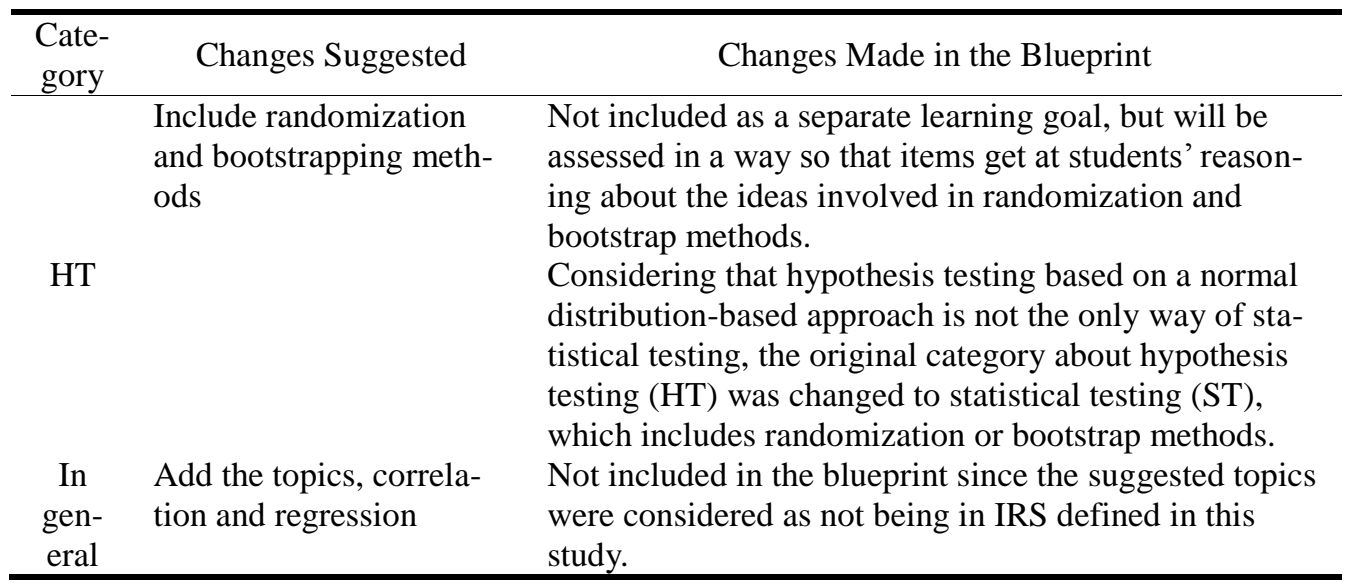

\section{SUMMARY AND NEXT STEP}

This study developed a test blueprint as a first step to design an assessment to measure students' inferential reasoning in statistics. The proposed assessment would help mathematics and statistics teachers understand how students interpret the concepts and ideas of statistical, so it gives the teachers useful information. As an assessment to measure a construct (in this study, IRS), it is necessary that the assessment covers multiple aspects of IRS (comprehensiveness of the test content) and that the test blueprint describing topics and learning goals helps instructors know what to look for when assessing IRS (a detailed and clear description of the blueprint).

The test domains were specified based on a thorough literature review, and the test blueprint was developed laying out important topics and learning goals of each domain. To ensure that the domains are representative to the contents in statistical inference and that the topics and learning goals are adequate to be measured in each domain, contents experts who are actively engaged in the field of statistics education were invited to evaluate the blueprint. For the preliminary version of test blueprint created from the literature review, experts agreed that the topics and learning goals are comprehensive and representative as test domains of IRS.

The reviewers generally considered the blueprint as a good resource to be used as a framework in assessing statistical inference. They acknowledged that the test blueprint covered multiple aspects of IRS. Suggestions and comments made from the reviewers were discussed with internal experts to make a decision on whether we implement in the final version of blueprint. The target population, the test domains, and test purposes were prioritized for the decision.

Using this test blueprint, in the next stage of this research study, the researcher will 
develop an assessment to measure students' inferential reasoning in statistics. This assessment would be different from conventional statistics tests that we can see in the textbooks in that the proposed test will focus on assessing students' ability to reason not simply asking memorized concepts or procedural knowledge. Moreover, this assessment will provide statistics instructors with useful information of what students misunderstand and how to design the courses by evaluating students' statistical reasoning in a wellstructured, coherent content domain. Thus, instructors can get better ideas of designing statistics curriculum to help students develop their inferential reasoning in statistics

\section{REFERENCES}

AERA; APA \& NCME (1999). Standards for educational psychological testing. Washington, DC: AERA.

American Statistical Association (2005). GAISE College Report. Retrieved from ASA GAISE College Report Web site: http://www.amstat.org/education/gaise/GAISECollege.htm

Batanero, C. (2000). Controversies around the role of statistical tests in experimental research. Mathematical Thinking and Learning 2(1-2), 75-97. ME 2001f.04627

Carver, R. P. (1978). The case against statistical significance testing. Harvard Educational Review 48(3), 378-399. Available from:

http://scholasticadministrator.typepad.com/thisweekineducation/files/the_case_against_statistic al_significance_testing.pdf

Chance, B.; delMas, R. \& Garfield, J. (2004). Reasoning about sampling distributions. In: D. BenZvi \& J. Garfield (Eds.), The Challenge of Developing Statistical Literacy, Reasoning and Thinking (pp. 295-323). Dordrecht, Netherlands: Kluwer Academic.

Cohen, J. (1994). The earth is round ( $\mathrm{p}<.05)$. American Psychologist, 49(12), 997-1003.

delMas, R. C.; Garfield, J. B. \& Chance, B. L. (1999). A model of classroom research in action: developing simulation activities to improve students' statistical reasoning. J. Stat. Educ. 7(3), 80K. ME 2000b.01311 Available from: http://www.amstat.org/publications/jse/secure/v7n3/delmas.cfm

Falk, R. (1986). Misconceptions of statistical significance. J. Struct. Learn. 9(1), 83-96. ME 1986h. 02861

Falk, R. \& Greenbaum, C. W. (1995). Significance tests die hard: The amazing persistence of a probabilistic misconception. Theory and Psychology 5(1), 75-98.

Garfield, J. (1998). The Statistical Reasoning Assessment: Development and Validation of a Research Tool. In L. Pereira Mendoza (Ed.), Proceedings of the Fifth International Conference on Teaching Statistics (pp. 781-786). Voorburg, The Netherlands: International Statistical Institute. Garfield, J. \& Ben-Zvi, D. (2008). Developing Students Statistical Reasoning: Connecting Re- 
search and Teaching Practice. Dordrecht, Netherlands: Springer. $\quad$ ME 2009b.00447

Garfield, J., delMas, R., \& Chance, B. (2002). "The Web-based ARTIST: Assessment Resource Tools for Improving Statistical Thinking” Project J. Stat. Educ. 7(3). [Online]. www.amstat.org/publications/jse/v5n3/giraud.html

Haller, H. \& Krauss, S. (2002). Misinterpretations of significance: A problem students share with their teachers? Methods of Psychological Research 7(1), 1-20.

Lipson, A. (2003). The role of the sampling distribution in understanding statistical inference. Mathematical Educational Research Journal 15(3), 270-287. Retrieved from: http://files.eric.ed.gov/fulltext/EJ776331.pdf

Liu, Y. \& Thompson, P. (2009). Mathematics teachers' understandings of proto-hypothesis testing. Pedagogies 4(2), 129-138.

Makar, K. \& Rubin, A. (2009). A framework for thinking about informal statistical inference. SERJ - Stat. Educ. Res. J. 8(1), 82-105. ME 2009e.00573 Retrieved from: http://www.stat.auckland.ac.nz/ iase/serj/SERJ8(1)_Makar_Rubin.pdf

Metz, K. E. (1999). Why sampling works or why it can't: Ideas of young children engaged in research of their own design. In: R. Hitt and M. Santos (Eds.), Proceedings of the Twenty-First Annual Meeting of the North American Chapter of the International Group for the Psychology of Education (pp. 492-498). Columbus, OH: 1999 ERIC Clearinghouse of Science, Mathematics, and Environmental Education.

Mittag, K. C. \& Thompson, B. (2000). A national survey of AERA members' perceptions of statistical significance tests and other statistical issues. Educational Researcher 29(4), 14-20.

Mokros, J. \& Russell, S. J. (1995). Children's concepts of average and representativeness. J. Res. Mathe. Educ. 26(1), 20-39. ME 1995f.03881

Nickerson, R. S. (2000). Null hypothesis significance testing: a review of an old and continuing controversy. Psychological Methods 5(2), 241-301.

Pfannkuch, M. (2005). Probability and statistical inference: How can teachers enable learners to make the connection? In: G. Jones (Ed.), Exploring probability in school: Challenges for teaching and learning (pp. 267-294). Dordrecht, Netherlands: Kluwer Academic.

Reed-Rhoads, T.; Murphy, T. J. \& Terry, R. (2006). The Statistics Concept Inventory: An Instrument for Assessing Student Understanding of Statistics Concepts, SIGMAA on Statistics Education session First Steps for Implementing the Recommendations of the Guidelines for Assessment and Instruction in Statistics Education (GAISE) College Report, Joint Mathematics Meetings, San Antonio, January 2006.

Rosenthal, R. (1993). Cumulating evidence. In: G. Keren (Ed.), A handbook of data analysis in the behavioral sciences: Methodological issues (pp. 519-559). Hillsdale, NJ: Erlbaum.

Rubin, A.; Bruce, B. \& Tenney, Y. (1991). Learning about sampling: Trouble at the core of statistics. In D. Vere-Jones (Ed.), Proceedings of the Third International Conference on Teaching Statistics (pp. 314-319). Dunedin, New Zealand: International Statistical Institute. 
Rubin, A.; Hammerman, J., \& Konold, C. (2006). Exploring informal inference with interactive visualization software. In: A. Rossman \& B. Chance (Eds.), Proceedings of the Seventh International Conference on Teaching Statistics (ICOTS) held at Salvador, Bahai, Brazil, July 2-7, 2006 (CD-ROM). Voorburg, Netherlands: International Statistical Institute.

Saldanha, L. (2004). "Is this sample unusual?": An investigation of students exploring connections between sampling distributions and statistical inference. Unpublished Ph.D. Thesis. Nashville, TN: Vanderbilt University.

Saldanha, L. \& Thompson, P. (2002). Conceptions of sample and their relationship to statistical inference. Educ. Stud. Math. 51(3), 257-270. ME 2003d.03486

Schwartz, D. L.; Goldman, S. R.; Vye, N. J.; Barron, B. J. \& Cognition Technology Group at Vanderbilt (1998). Aligning everyday and mathematical reasoning: The case of sampling assumptions. In: S. Lajoie (Ed.), Reflections on Statistics: Learning, Teaching, and Assessment in Grades K-12 (pp. 233-273). Hillsdale, NJ: Erlbaum.

Sedlemeier, P. \& Gigerenzer, G. (1997). Intuitions about sample size: The empirical law of large numbers. Journal of Behavior Decision Making 10, 33-51.

Sotos, A. E. C.; Vanhoof, S.; Van den Noortgate, W. \& Onghena, P. (2007). Students' misconceptions of statistical inference: A review of the empirical evidence from research on statistics education. Educational Research Review 2, 98-113.

Tversky, A. \& Kahneman, D. (1971). Belief in the law of small numbers. Psychological Bulletin 76, 105-110. [Reprinted in: D. Kahneman, P. Slovic \& A. Tversky (1982), Judgment under uncertainty: Heuristics and biases. Cambridge University Press.]

Tversky, A. \& Kahneman, D. (1974). Judgment under uncertainty: Heuristics and biases. Science 185(4157), 1124-1131. Retrieved from: http://files.eric.ed.gov/fulltext/EJ776331.pdf

Vallecillos, A. (1999). Some empirical evidences on learning difficulties about testing hypotheses. In: Proceedings of the 52 session of the International Statistical Institute (pp. 201-204). Helsinki: International Statistical Institute. Retrieved from: https://www.stat.auckland.ac.nz/ iase/publications/5/vall0682.pdf

Vallecillos, A. (2002). Empirical evidence about understanding of the level of significance concept in hypotheses testing by university students. Themes in Education 3(2), 183-198.

Vallecillos, A. \& Batanero, C. (1997). Activated concepts in the statistical hypothesis contrast and their understanding by unversity students. Reserchers en Didactique des Mathematiques 17, $29-48$.

Vanhoof, S.; Sotos, A.; Onghena, P. \& Verschaffel, L. (2007). Students' reasoning about sampling distribution before and after the sampling distribution activity. In: Proceedings of the 56 session of the International Statistical Institute, Lisbon, Spain, International Statistical Institute. [Online]: www.stat.auckland.ac.nz/ iase/publications/isi56/CPM80_Vanhoof.pdf.

Wagner, D. A. \& Gal, I. (1991). Project STARC: Acquisition of statistical reasoning in children. 
(Annual Report: Year 1, NSF Grant No. MDR90-50006). Philadelphia, PA: Literacy Research Center, University of Pennsylvania.

Watson, J. M. \& Moritz, J. B. (2000a). Developing concepts of sampling. J. Res. Math. Educ.

31(1), 44-70. ME 2000e.03613

(2000b). The longitudinal development of understanding of average. Math. Think. Learn. 2(1-2), 11-50. ME 2000d.02870 ME 2001f. 05345

Well, A.; Pollastek, A. \& Boyce, S. (1990). Understanding of the effects of sample size on the variability of the mean. Organizational Behavior and Human Decision Processes 47, 289-312.

Wild, C. K.; Pfannkuch, M.; Regan, M. \& Horton, N. J. (2011). Towards more accessible conceptions of statistical inference. J. Royal Statistical Society A. 174(2), 1-23.

Retrieved November 7, 2010, from: http://www.rss.org.uk/pdf/Wild_Oct._2010.pdf

Wilkerson, M. \& Olson, J. R. (1997). Misconceptions about sample size, statistical significance, and treatment effect. Journal of Psychology 131(6), 627-631.

Williams, A. M. (1999). Novice students' conceptual knowledge of statistical hypothesis testing. In: J. M. Truran and K.M. Truran (Eds.), Making the difference: Proceedings of the Twenty-second Annual Conference of the Mathematics Education Research Group of Australasia (pp. 554560). Adelaide, Australia: MERGA. ME 2000e. 03645

Zieffler, A.; Garfield, J.; delMas, R. \& Reading, C. (2008). A framework to support research on informal inferential reasoning. SERJ - Stat. Edu. Res. J. 7(2), 40-58. ME 2009e.00120 


\section{APPENDIX A. PRELIMINARY TEST BLUEPRINT}

Table 3. Test Blueprint to Assess Informal Statistical Inference

(Topic Category: Informal Inference)

\begin{tabular}{|c|c|c|c|}
\hline $\begin{array}{l}\text { Cate- } \\
\text { gory }\end{array}$ & Topics & Learning Goals & Literature \\
\hline Inf-1 & $\begin{array}{l}\text { The con- } \\
\text { cept of } \\
\text { uncertainty }\end{array}$ & $\begin{array}{l}\text { Being able to express uncertainty in making } \\
\text { inference using probabilistic (not determinis- } \\
\text { tic) language }\end{array}$ & $\begin{array}{l}\text { Makar \& Rubin (2009); } \\
\text { Zieffler et al. (2008) }\end{array}$ \\
\hline Inf-2 & $\begin{array}{l}\text { Properties } \\
\text { of aggre- } \\
\text { gates }\end{array}$ & $\begin{array}{l}\text { Being able to able to reason about a collec- } \\
\text { tion of data from individual cases as an ag- } \\
\text { gregate }\end{array}$ & $\begin{array}{l}\text { Makar \& Rubin (2009); } \\
\text { Rubin, Hammerman \& } \\
\text { Konold (2006); Pfann- } \\
\text { kuch (1999) }\end{array}$ \\
\hline Inf-3 & $\begin{array}{l}\text { Sampling } \\
\text { variability }\end{array}$ & $\begin{array}{l}\text { - Understanding } \\
\text { - The nature and behavior of sampling vari- } \\
\text { ability } \\
\text { - Understanding sample to sample variabil- } \\
\text { ity } \\
\text { - Taking into account sample size in associ- } \\
\text { ation with sampling variability }\end{array}$ & $\begin{array}{l}\text { Rubin, Hammerman \& } \\
\text { Konold (2006); } \\
\text { Wild et al. (2011) }\end{array}$ \\
\hline Inf-4 & $\begin{array}{l}\text { The con- } \\
\text { cept of } \\
\text { unusual- } \\
\text { ness }\end{array}$ & $\begin{array}{l}\text { Being able to understand and articulate } \\
\text { whether or not a particular sample of data is } \\
\text { likely given a particular expectation or claim }\end{array}$ & $\begin{array}{l}\text { Makar \& Rubin (2009); } \\
\text { Zieffler et al. (2008); } \\
\text { Liu \& Thompson (2009) }\end{array}$ \\
\hline Inf-5 & $\begin{array}{l}\text { Generaliz- } \\
\text { ing from a } \\
\text { sample to a } \\
\text { population }\end{array}$ & $\begin{array}{l}\text { - Being able to predict and reason about } \\
\text { possible characteristics of a population } \\
\text { based on a sample of data } \\
\text { - Being able to draw a conclusion about } \\
\text { population from sample(s) based on the } \\
\text { prediction }\end{array}$ & Zieffler et al. (2008) \\
\hline Inf-6 & $\begin{array}{l}\text { Reasoning } \\
\text { about } \\
\text { compari- } \\
\text { son of two } \\
\text { popula- } \\
\text { tions from } \\
\text { two sam- } \\
\text { ples }\end{array}$ & $\begin{array}{l}\text { - Being able to predict and reason about } \\
\text { possible differences between two popula- } \\
\text { tions based on observed differences be- } \\
\text { tween two samples of data } \\
\text { - Being able to draw a conclusion about } \\
\text { comparison of two populations from two } \\
\text { samples based on the prediction }\end{array}$ & $\begin{array}{l}\text { Wild et al. (2011); } \\
\text { Makar \& Rubin, (2009); } \\
\text { Zieffler et al. (2008); } \\
\text { Pfannkuch, (2005) }\end{array}$ \\
\hline
\end{tabular}


Table 4. Test Blueprint to Assess Informal Statistical Inference

(Topic Categories: Sampling distribution (SD) and Hypothesis testing (HT))

\begin{tabular}{|c|c|c|c|c|}
\hline $\begin{array}{l}\text { Cate- } \\
\text { gory }\end{array}$ & Topics & Learning Goals & $\begin{array}{l}\text { Misconceptions } \\
\text { Found } \\
\text { in Literature }\end{array}$ & Literature \\
\hline SD-1 & $\begin{array}{l}\text { The con- } \\
\text { cepts of } \\
\text { samples and } \\
\text { sampling }\end{array}$ & $\begin{array}{l}\text { - Understanding the } \\
\text { definition of sam- } \\
\text { pling distribution } \\
\text { - Understanding the } \\
\text { role of sampling } \\
\text { distribution }\end{array}$ & $\begin{array}{l}\text { A tendency to pre- } \\
\text { dict sample out- } \\
\text { comes based on } \\
\text { causal analyses in- } \\
\text { stead of statistical } \\
\text { patterns in a collec- } \\
\text { tion of sample out- } \\
\text { comes }\end{array}$ & $\begin{array}{l}\text { Saldanha \& Thomp- } \\
\text { son (2002); Sald- } \\
\text { hanha (2004); Rubin, } \\
\text { Bruce \& Tenney } \\
\text { (1991) }\end{array}$ \\
\hline SD-2 & $\begin{array}{l}\text { Law of } \\
\text { Large Num- } \\
\text { bers (Sample } \\
\text { representa- } \\
\text { tiveness) }\end{array}$ & $\begin{array}{l}\text { Understanding that } \\
\text { the larger the sample, } \\
\text { the closer the distri- } \\
\text { bution of the sample } \\
\text { is expected to be to } \\
\text { the population distri- } \\
\text { bution }\end{array}$ & $\begin{array}{l}\text { A tendency to as- } \\
\text { sume that a sample } \\
\text { represents the popu- } \\
\text { lation regardless of } \\
\text { sample size (repre- } \\
\text { sentativeness heu- } \\
\text { ristic) }\end{array}$ & $\begin{array}{l}\text { Kahneman \& } \\
\text { Tversky; Rubin et al. } \\
\text { (1991); Saldanha \& } \\
\text { Thompson (2002); } \\
\text { Metz (1999); Watson } \\
\text { \& Moritz, (2000a; } \\
\text { 2000b) }\end{array}$ \\
\hline SD-3 & $\begin{array}{l}\text { Population } \\
\text { distribution } \\
\text { and frequen- } \\
\text { cy distribu- } \\
\text { tions }\end{array}$ & $\begin{array}{l}\text { Understanding the } \\
\text { relationship between } \\
\text { frequency distribu- } \\
\text { tion and population } \\
\text { distribution }\end{array}$ & $\begin{array}{l}\text { Confusion between } \\
\text { frequency distribu- } \\
\text { tions and sampling } \\
\text { distributions }\end{array}$ & $\begin{array}{l}\text { Sedlemeier \& } \\
\text { Gigerenzer (1997); } \\
\text { Lipson (2003); } \\
\text { delMas et al. (1999) }\end{array}$ \\
\hline SD-4 & $\begin{array}{l}\text { Population } \\
\text { distribution } \\
\text { and sam- } \\
\text { pling distri- } \\
\text { butions }\end{array}$ & $\begin{array}{l}\text { Understanding the } \\
\text { relationship between } \\
\text { sampling distribution } \\
\text { and population distri- } \\
\text { bution }\end{array}$ & $\begin{array}{l}\text { Confusion between } \\
\text { population and } \\
\text { sampling distribu- } \\
\text { tions }\end{array}$ & delMas et al. (1999) \\
\hline SD-5 & $\begin{array}{l}\text { Central Lim- } \\
\text { it Theorem }\end{array}$ & $\begin{array}{l}\text { - Understanding the } \\
\text { effect of sample } \\
\text { size in sampling } \\
\text { distributions } \\
\text { - Understanding how } \\
\text { sampling error is } \\
\text { related to making } \\
\text { an inference about } \\
\text { a sample mean }\end{array}$ & $\begin{array}{l}\text { Lack of taking into } \\
\text { account sample size } \\
\text { in association with } \\
\text { distributions of } \\
\text { samples }\end{array}$ & $\begin{array}{l}\text { Mokros \& Russell } \\
\text { (1995); Sedlemeier \& } \\
\text { Gigerenzer (1997); } \\
\text { Tversky \& Kahne- } \\
\text { man, (1974); Vanhoof } \\
\text { et al. (2007); } \\
\text { Schwartz, Goldman, } \\
\text { Vye, Barron \& Cog- } \\
\text { nition Technology } \\
\text { Group at Vanderbilt } \\
\text { (1998); } \\
\text { Wagner \& Gal } \\
\text { (1991); Well, Pol- } \\
\text { lastek \& Boyce } \\
\text { (1990) }\end{array}$ \\
\hline
\end{tabular}




\begin{tabular}{|c|c|c|c|c|}
\hline $\begin{array}{l}\text { Cate- } \\
\text { gory }\end{array}$ & Topics & Learning Goals & $\begin{array}{l}\text { Misconceptions } \\
\text { Found } \\
\text { in Literature }\end{array}$ & Literature \\
\hline HT-1 & $\begin{array}{l}\text { Definition, } \\
\text { role, and } \\
\text { logic of hy- } \\
\text { pothesis test- } \\
\text { ing }\end{array}$ & $\begin{array}{l}\text { Being able to de- } \\
\text { scribe the null hy- } \\
\text { pothesis } \\
\text { Understanding the } \\
\text { logic of a signifi- } \\
\text { cance test }\end{array}$ & $\begin{array}{l}\text { - Failing to reject } \\
\text { the null is equiva- } \\
\text { lent to demon- } \\
\text { strating it to be } \\
\text { true (Lack of un- } \\
\text { derstanding the } \\
\text { conditional logic } \\
\text { of significance } \\
\text { tests) } \\
\text { - Lack of under- } \\
\text { standing the role } \\
\text { of hypothesis } \\
\text { testing as a tool } \\
\text { for making a de- } \\
\text { cision }\end{array}$ & $\begin{array}{l}\text { Batanero (2000); } \\
\text { Nickerson (2000); } \\
\text { Haller \& Krauss } \\
\text { (2002); Liu \& } \\
\text { Thompson (2009); } \\
\text { Vallecillos (2002); } \\
\text { Williams (1999); } \\
\text { Mittag \& Thompson } \\
\text { (2000) }\end{array}$ \\
\hline HT-2 & $\begin{array}{l}\text { Definitions } \\
\text { of } P \text {-value } \\
\text { and statisti- } \\
\text { cal signifi- } \\
\text { cance }\end{array}$ & $\begin{array}{l}\text { Being able to recog- } \\
\text { nize a correct inter- } \\
\text { pretation of a } P \text {-value }\end{array}$ & $\begin{array}{l}\text { Misconception: } P \text { - } \\
\text { value is the proba- } \\
\text { bility that the null } \\
\text { hypothesis is true } \\
\text { and that (1-p) is the } \\
\text { probability that the } \\
\text { alternative hypothe- } \\
\text { sis is true }\end{array}$ & $\begin{array}{l}\text { Carver (1978); } \\
\text { Falk \& Greenbaum } \\
(1995) ; \\
\text { Nickerson }(2000)\end{array}$ \\
\hline HT-3 & $\begin{array}{l}P \text {-value as a } \\
\text { numerical } \\
\text { probability }\end{array}$ & $\begin{array}{l}\text { Understanding the } \\
\text { smaller the } P \text {-value, } \\
\text { the stronger the evi- } \\
\text { dence of a difference } \\
\text { of effect } \\
\text { Understanding the } \\
\text { relationship between } \\
P \text {-value and standard } \\
\text { error (Understanding } \\
\text { that given the same } \\
\text { mean difference, the } \\
\text { smaller the variation } \\
\text { in the sample statis- } \\
\text { tic, the smaller the } P \text { - } \\
\text { value, if all else re- } \\
\text { mains the same) }\end{array}$ & $\begin{array}{l}\text { Misconception: A } \\
\text { small } P \text {-value } \\
\text { means a treatment } \\
\text { effect of large mag- } \\
\text { nitude }\end{array}$ & $\begin{array}{l}\text { Cohen (1994); } \\
\text { Rosenthal (1993) }\end{array}$ \\
\hline
\end{tabular}




\begin{tabular}{|c|c|c|c|c|}
\hline $\begin{array}{l}\text { Cate- } \\
\text { gory }\end{array}$ & Topics & Learning Goals & $\begin{array}{c}\text { Misconceptions } \\
\text { Found } \\
\text { in Literature }\end{array}$ & Literature \\
\hline HT-4 & $\begin{array}{l}\text { Sample size } \\
\text { and statisti- } \\
\text { cal signifi- } \\
\text { cance in HT }\end{array}$ & $\begin{array}{l}\text { - Understanding } \\
\text { larger sample sizes } \\
\text { yield smaller } P \text { - } \\
\text { values, and more } \\
\text { statistically signifi- } \\
\text { cant observed re- } \\
\text { sults, if all else re- } \\
\text { mains the same }\end{array}$ & $\begin{array}{l}\text { Lack of understand- } \\
\text { ing the relationship } \\
\text { between sample } \\
\text { size and statistical } \\
\text { significance }\end{array}$ & $\begin{array}{l}\text { Wilkerson \& Olson } \\
\text { (1997) }\end{array}$ \\
\hline HT-5 & $\begin{array}{l}\text { Evaluation } \\
\text { of HT }\end{array}$ & $\begin{array}{l}\text { Understanding that an } \\
\text { experimental design } \\
\text { with random assign- } \\
\text { ment supports causal } \\
\text { inference } \\
\text { Being able to make } \\
\text { an appropriate con- } \\
\text { clusion from a hy- } \\
\text { pothesis test }\end{array}$ & $\begin{array}{l}\text { Lack of interpreta- } \\
\text { tion of result of } \\
\text { hypothesis testing } \\
\text { and statistical sig- } \\
\text { nificance }\end{array}$ & $\begin{array}{l}\text { Wilkerson \& Olson } \\
\text { (1997) }\end{array}$ \\
\hline HT-6 & $\begin{array}{l}\text { Designing a } \\
\text { statistical } \\
\text { test for the } \\
\text { comparison }\end{array}$ & $\begin{array}{l}\text { Being able to design } \\
\text { a statistical test to } \\
\text { compare two samples } \\
\text { from a population } \\
\text { Being able to make a } \\
\text { conclusion from a } \\
\text { statistical test }\end{array}$ & & \\
\hline
\end{tabular}




\section{APPENDIX B. FINAL VERSION TEST BLUEPRINT}

Table 5. Test Blueprint to Assess Informal Inference

(Topic Category: Informal Inference)

\begin{tabular}{|c|c|c|}
\hline $\begin{array}{l}\text { Cate- } \\
\text { gory }\end{array}$ & Topics & Learning Goals \\
\hline Inf-1 & $\begin{array}{l}\text { The concept of } \\
\text { uncertainty }\end{array}$ & $\begin{array}{l}\text { Being able to express uncertainty in making inference using proba- } \\
\text { bilistic (not deterministic) language }\end{array}$ \\
\hline Inf-2 & $\begin{array}{l}\text { Properties of } \\
\text { aggregates }\end{array}$ & $\begin{array}{l}\text { Being able to able to reason about a collection of data from individ- } \\
\text { ual cases as an aggregate }\end{array}$ \\
\hline Inf-3 & $\begin{array}{l}\text { Sampling var- } \\
\text { iability }\end{array}$ & $\begin{array}{l}\text { - Understanding } \\
\text { - The nature and behavior of sampling variability } \\
\text { - Understanding sample to sample variability } \\
\text { - Taking into account sample size in association with sampling } \\
\text { variability }\end{array}$ \\
\hline Inf-4 & $\begin{array}{l}\text { The concept of } \\
\text { unusualness }\end{array}$ & $\begin{array}{l}\text { Being able to understand and articulate whether or not a particular } \\
\text { sample of data is likely given a particular expectation or claim }\end{array}$ \\
\hline Inf-5 & $\begin{array}{l}\text { Generalizing } \\
\text { from a sample } \\
\text { to a population }\end{array}$ & $\begin{array}{l}\text { - Being able to predict and reason about possible characteristics of } \\
\text { a population based on a sample of data } \\
\text { - Being able to draw a conclusion about population from sample(s) } \\
\text { based on the prediction }\end{array}$ \\
\hline Inf-6 & $\begin{array}{l}\text { Reasoning } \\
\text { about compar- } \\
\text { ison of two } \\
\text { populations } \\
\text { from two } \\
\text { samples }\end{array}$ & $\begin{array}{l}\text { - Being able to predict and reason about possible differences be- } \\
\text { tween two populations based on observed differences between } \\
\text { two samples of data } \\
\text { - Being able to draw a conclusion about comparison of two popula- } \\
\text { tions from two samples based on the prediction }\end{array}$ \\
\hline Inf-7 & $\begin{array}{l}\text { Comparing } \\
\text { two samples } \\
\text { from two pop- } \\
\text { ulations }\end{array}$ & $\begin{array}{l}\text { - Being able to predict and reason about possible differences be- } \\
\text { tween two populations based on observed differences between } \\
\text { two samples of data } \\
\text { - Being able to draw a conclusion about two populations } \\
\text { - Being able to take into account sample variations or sample size } \\
\text { in relation with evidence to compare two samples }\end{array}$ \\
\hline
\end{tabular}


Table 6. Test Blueprint to Assess Informal Inference

(Topic Categories: Sampling distribution (SD) and Design of study (DE))

\begin{tabular}{|c|c|c|}
\hline $\begin{array}{l}\text { Cate- } \\
\text { gory }\end{array}$ & Topics & Learning Goals \\
\hline SD-1 & $\begin{array}{l}\text { The concepts of } \\
\text { samples and sam- } \\
\text { pling }\end{array}$ & $\begin{array}{l}\text { - Understanding the definition of sampling distribution } \\
\text { - Understanding the role of sampling distribution }\end{array}$ \\
\hline SD-2 & $\begin{array}{l}\text { Sample representa- } \\
\text { tiveness }\end{array}$ & $\begin{array}{l}\text { - Understanding importance of random sampling (recognizing } \\
\text { biased sampling) } \\
\text { - Law of Large Numbers (Understanding that the larger the } \\
\text { sample, the closer the distribution of the sample } \\
\text { - is expected to be to the population distribution) }\end{array}$ \\
\hline SD-3 & $\begin{array}{l}\text { Population distribu- } \\
\text { tion, sample distri- } \\
\text { butions, and sam- } \\
\text { pling distribution }\end{array}$ & $\begin{array}{l}\text { - Understanding the relationship between sample distribution } \\
\text { and population distribution } \\
\text { - Understanding the relationship between sampling distribu- } \\
\text { tion and population distribution }\end{array}$ \\
\hline SD-4 & $\begin{array}{l}\text { Central Limit Theo- } \\
\text { rem }\end{array}$ & $\begin{array}{l}\text { - Understanding the effect of sample size in sampling distri- } \\
\text { butions } \\
\text { - Understanding how sampling error is related to making an } \\
\text { inference about a sample mean }\end{array}$ \\
\hline $\mathrm{DE}$ & Study design & $\begin{array}{l}\text { - Understanding the logic of experimental design } \\
\text { - Understanding difference between observational and exper- } \\
\text { imental study } \\
\text { - Understanding the purpose of random assignment in an ex- } \\
\text { perimental study }\end{array}$ \\
\hline $\mathrm{EV}$ & $\begin{array}{l}\text { Generalizing the } \\
\text { results of ST } \\
\text { Evaluation of ST }\end{array}$ & $\begin{array}{l}\text { - Understanding that an experimental design with random } \\
\text { assignment supports causal inference } \\
\text { - Understanding that an observational design with no random } \\
\text { assignment doesn't support causal inference } \\
\text { - Being able to evaluate the results of hypothesis testing (con- } \\
\text { sidering sample size, practical significance, } \\
\text { - effect size, data quality, soundness of the method, etc. }\end{array}$ \\
\hline
\end{tabular}


(Topic Categories: Statistical testing (ST) and Confidence interval (CI))

\begin{tabular}{|c|c|c|}
\hline $\begin{array}{l}\text { Cate- } \\
\text { gory }\end{array}$ & Topics & Learning Goals \\
\hline ST-1 & $\begin{array}{l}\text { Definitions of } P \text { - } \\
\text { value and statisti- } \\
\text { cal significance }\end{array}$ & $\begin{array}{l}\text { - Being able to recognize a correct interpretation of a P-value } \\
\text { - Being able to calculate a numerical P-value from a given } \\
\text { distribution of statistics } \\
\text { - Being able to recognize a correct interpretation of statistical } \\
\text { significance }\end{array}$ \\
\hline ST-2 & $\begin{array}{l}\text { A statistical test } \\
\text { for the compari- } \\
\text { son }\end{array}$ & $\begin{array}{l}\text { - Being able to design a statistical test to compare two sam- } \\
\text { ples from two population } \\
\text { - Designing a statistical test to compare two groups in an ex- } \\
\text { periment } \\
\text { - Being able to make a conclusion from a statistical test for } \\
\text { comparing two groups }\end{array}$ \\
\hline ST-3 & $\begin{array}{l}\text { Inference about a } \\
\text { population pro- } \\
\text { portion }\end{array}$ & $\begin{array}{l}\text { - Designing a statistical test for the proportion given in a } \\
\text { sample } \\
\text { - Making a conclusion about a statistical test for the popula- } \\
\text { tion proportion }\end{array}$ \\
\hline ST-4 & $\begin{array}{l}\text { Inference about } \\
\text { comparing two } \\
\text { proportions }\end{array}$ & $\begin{array}{l}\text { - Being able to set up the null model to compare two propor- } \\
\text { tions } \\
\text { - Being able to make a conclusion about a statistical test for } \\
\text { comparing two population proportions }\end{array}$ \\
\hline CI & $\begin{array}{l}\text { Inference about } \\
\text { Confidence Inter- } \\
\text { vals }\end{array}$ & $\begin{array}{l}\text { - Being able to interpret confidence interval in a given con- } \\
\text { text } \\
\text { - Being able to interpret the relationship between confidence } \\
\text { interval and margin of error }\end{array}$ \\
\hline
\end{tabular}




\section{APPENDIX C. EXPERTS' COMMENTS AND CHANGED IMPLEMENTED}

Table 7. Experts' Comments and Changed Implemented (or Not Implemented) in the Final Blueprint

(Common suggestions)

Comments and Suggestions

Changes Made in Final Blueprint

(Included or Not Included in Blueprint)

In the category of Informal inference, there is no attention to inferences about the real world Added some learning goals which consider inferential reasoning in a given context or contextual knowledge. (Reviewer 1 and 2)

Formal inference (SD and ST) is too focusing on the limited population. (Reviewer 1 and 3)

Added the topics, DE (DEsign of study) and EV (evaluation of study) to get at students' understanding of characteristics of different types of study in terms of - how to design the study and how to generalize the results of the study

Need to have learning goals about understanding of effect In the category EV, added the learning goal, "Being able to size (Reviewer 2 and 3) evaluate the results of hypothesis testing considering sample size, practical significance, effect size, data quality, soundness of the method, etc.

\begin{tabular}{lll}
\hline (Suggestions from Reviewer 1) & \multicolumn{2}{c}{ Changes Made in Final Blueprint } \\
\hline \multirow{2}{*}{ Comments and Suggestions } & $\begin{array}{c}\text { Included or Not Included in } \\
\text { Blueprint }\end{array}$ & Rationale for Not Included \\
\cline { 2 - 3 } $\begin{array}{l}\text { Too focus on one type of prob- } \\
\text { lem, differences between } \\
\text { groups, but almost half of the } \\
\text { problems are about correlation } \\
\text { problems (and regression). }\end{array}$ & $\begin{array}{l}\text { Not included in the blueprint } \\
\text { Correlation and regression } \\
\text { were considered as literacy } \\
\text { or part of descriptive sta- } \\
\text { tistics rather than use of } \\
\text { inferential reasoning }\end{array}$ \\
$\begin{array}{l}\text { Include learning goals about } \\
\text { "Using models in informal in- } \\
\text { ferential reasoning" }\end{array}$ & $\begin{array}{l}\text { In two categories, informal } \\
\text { inference and formal infer- } \\
\text { ence, the learning goals } \\
\text { about setting up the null } \\
\text { model in a given context } \\
\text { was added. }\end{array}$ \\
\hline
\end{tabular}




\begin{tabular}{|c|c|c|}
\hline \multirow[b]{2}{*}{ Comments and Suggestions } & \multicolumn{2}{|c|}{ Changes Made in Final Blueprint } \\
\hline & $\begin{array}{l}\text { Included or Not Included in } \\
\text { Blueprint }\end{array}$ & Rationale for Not Included \\
\hline $\begin{array}{l}\text { Include using meta-cognitive } \\
\text { awareness what inference is as } \\
\text { opposed to performing some } \\
\text { techniques }\end{array}$ & Not included in the blueprint & $\begin{array}{l}\text { This learning goal was } \\
\text { considered to be difficult } \\
\text { to assess using typical test } \\
\text { format (online format or } \\
\text { paper-and-pencil format). } \\
\text { Meta-cognitive awareness } \\
\text { can be assessed through in- } \\
\text { depth interview or individ- } \\
\text { ual observation. }\end{array}$ \\
\hline $\begin{array}{l}\text { Too focus on one type of prob- } \\
\text { lem, differences between } \\
\text { groups, but almost half of the } \\
\text { problems are about correlation } \\
\text { problems (and regression) }\end{array}$ & Not included in the blueprint & $\begin{array}{l}\text { Correlation and regression } \\
\text { were considered as literacy } \\
\text { or part of descriptive sta- } \\
\text { tistics rather than use of } \\
\text { inferential reasoning }\end{array}$ \\
\hline $\begin{array}{l}\text { Include learning goals about } \\
\text { "Using models in informal in- } \\
\text { ferential reasoning" }\end{array}$ & $\begin{array}{l}\text { In two categories, informal } \\
\text { inference and formal infer- } \\
\text { ence, the learning goals } \\
\text { about setting up the null } \\
\text { model in a given context } \\
\text { was added. }\end{array}$ & \\
\hline $\begin{array}{l}\text { Include using meta-cognitive } \\
\text { awareness what inference is as } \\
\text { opposed to performing some } \\
\text { techniques }\end{array}$ & Not included in the blueprint & $\begin{array}{l}\text { This learning goal was } \\
\text { considered to be difficult } \\
\text { to assess using typical test } \\
\text { format (online format or } \\
\text { paper-and-pencil format). } \\
\text { Meta-cognitive awareness } \\
\text { can be assessed through in- } \\
\text { depth interview or individ- } \\
\text { ual observation. }\end{array}$ \\
\hline $\begin{array}{l}\text { Describe more explicitly about } \\
\text { concepts like distribution, center } \\
\text { and variation in aggregate cate- } \\
\text { gory }\end{array}$ & $\begin{array}{l}\text { In the category of Properties } \\
\text { of aggregates the learning } \\
\text { goal, Being able to able to } \\
\text { describe a collection of data } \\
\text { using properties of distribu- } \\
\text { tion (shape, center, and var- } \\
\text { iation but not necessarily } \\
\text { using the terms), was added. }\end{array}$ & \\
\hline
\end{tabular}


(Suggestions from Reviewer 2)

Comments and Suggestions

Changes Made in Final Blueprint

(Included or Not Included in Blueprint)

Need to develop a topic catego- The topic category, "Inference about Confidence Interval, ry on Confidence Intervals CI" was added.

Need to consider data quality, soundness of the method etc.

The topic category, "Evaluation of HT (EV)", was separated out from the Hypothesis Testing categories since this topic is more about assessing how to interpret and evaluate the results from statistical testing by integrating different kinds of information in a given study (e.g., random assignment, sample size, data quality). The learning goal about, "Being able to evaluate the results of hypothesis testing (considering sample size, practical significance, effect size, data quality, soundness of the method, etc.)", was included in this EV category.

In HT-6, add designing a test to compare two groups in an ex-

In ST-3 (changed from category of HT), the learning goal, designing a statistical test to compare two groups in an periment. You might take samples from volunteers, not from experiment, was added.

populations.

Consider including randomization and bootstrapping methods
Not included as a separate learning goals, but will be assessed in a way that items get at students reasoning of the ideas involved in randomization and bootstrap methods.

Considering that hypothesis testing based on normal distribution-based approach is not the only way of statistical testing, the original category about hypothesis testing (HT) was changed to statistical testing (ST), which includes randomization or bootstrap methods.

\begin{tabular}{ll}
\hline (Suggestions from Reviewer 3) & \multicolumn{1}{c}{$\begin{array}{c}\text { Changes Made in Final Blueprint } \\
\text { (Included or Not Included in Blueprint) }\end{array}$} \\
\hline $\begin{array}{l}\text { For SD-2, in addition to "how } \\
\text { larger samples look more like } \\
\text { the population", it is much more } \\
\text { important "biased sampling" for } \\
\text { sampling representativeness }\end{array}$ & $\begin{array}{l}\text { The topic of "Law of Large Numbers" was changed to } \\
\text { "sample representativeness" to assess whether students } \\
\text { realize the importance of unbiased sampling (quality of } \\
\text { samples) in addition to a large number of a sample (quanti- } \\
\text { ty of samples) }\end{array}$ \\
\hline
\end{tabular}

